\title{
FACTORS AFFECTING STUDENTS' UNDERSTANDING OF THE QUALITY OF HIGHER EDUCATION
}

\author{
Irina Degtjarjova, Inga Lapina \\ Riga Technical University, Latvia
}

\begin{abstract}
Students are the main stakeholders in the higher education area so their involvement is closely related to the quality of higher education. There are a lot of factors that affect the understanding of the quality of higher education. Factors are used for quality planning, assessment, assurance, control, improvement etc. The research question is: what factors affect students' understanding of the quality of higher education?

The research was conducted in two stages. During the first stage of the research, the concept of the quality of higher education was analysed by using literature review and focus group discussion. During the second stage, a questionnaire was developed and students of the Faculty of Engineering Economics and Management of Riga Technical University (RTU FEEM) were surveyed, the results of students' survey were analysed by using Spearman rank correlation.

The research shows that there are three groups of factors that affect students' understanding of the quality of higher education: factors related to the study process (SP), support and resources (SR), and external factors and results (EFR). As a result of correlation analysis, SP factors have more internal correlations within the group, while SR and EFR factors more correlate with each other. The most significant factors that affect students' understanding of the quality of higher education are the quality of educational content and professors' competence.

Some trends were observed: (1) factors with a small number of correlations have more internal correlations than intergroup correlations; (2) the more important is the factor, the greater is the number of relationships, and vice versa; (3) the more important is the factor, the closer are relationships, and vice versa. There is one exception recognised in the research: although the factor 'Quality of educational content', according to the students, is the most important factor, the correlation analysis shows that it has no statistically significant correlations with other factors.
\end{abstract}

Keywords: factors, higher education, quality, students, understanding of the quality. 


\section{Introduction}

Quality is one of the most strategic drivers of higher education (Rossouw \& Goldman, 2014). Modern managers, including management of higher education institutions (HEIs), are actively analysing directions of industry development and looking for solutions to ensure that the organization meets the requirements of the industry, the stakeholders, and education policies (Dahlgaard-Park, 2008; Iljins et al., 2015; Iljins et al., 2017; Ozoliņš et al., 2018; Straujuma et al., 2017).

HEIs operating in global settings cannot focus solely on the needs of the local labour market and methods and content of classical education. For Latvia, regaining its independence in 1991 was the starting point of a new stage in higher education and understanding of the notion of quality. In the last decades quality criteria and assessment procedures have changed both at the national and European levels. In 2015, the student-centred learning principle was included in the Standards and Guidelines for Quality Assurance in the European Higher Education Area. Student-centred learning moves students from passive receivers of information to active participants. To increase stakeholders' mutual understanding of the quality of higher education is one of the most important condition for aimed and gradual quality improvement - step by step, in coordination with stakeholders.

Universities need not only to develop and ensure harmonised quality management system, but to achieve a high level of staff's involvement in quality improvement. Each staff member needs to accept the quality as everyone's own value and part of their behavioural system (Lanarès, 2008).

On the one hand, quality can be seen as meeting minimum requirements. On the other hand, quality is seen as excellence. The concept of quality ranges from meaning "standards" to meaning "excellence". It is impossible to draw a line between levels of requirements, and it is impossible to separate the requirements of quality of input, process and output. In the second strategy specific indicators are used. The indicators that focus more on inputs are administrative, student support, instructional (Schindler et al., 2015), on process - procedural quality (Sallis, 2002), on outputs student performance, employability etc. (Støren \& Aamodt, 2010).

Socio-economic and geopolitical settings, new generations' behaviour models, fast development of knowledge and technologies with a simultaneous outdating process, continuous educational process create a necessity for HEIs to introduce innovative quality management system and new forms of co-operation that are based on unified understanding of quality of higher education (Medne et al., 2020; Setijono \& Dahlgaard, 2007).

When providing the quality of higher education, universities are affected by several stakeholders: students and their parents, employers, ministry 
of education and science, society, teaching staff and administrative staff, investors, taxpayers and others. Much of the literature on quality in education focuses on the student as a customer. In order to deliver high quality services to students, universities must manage every aspect of students' interaction with all of their service offering, student judgement of university experience is based on what happens within and beyond the classroom (Douglas et al., 2006).

The results of the majority of studies show that students are the most important stakeholders (Geryk, 2018; Mainardes et al., 2010; Shah \& Nair, 2010). According to Paricio, in the terms of a new paradigm, students are true customers of modern higher education:

"The idea of student-customers [..] is part of an entirely new paradigm in higher education, which also includes [..] the idea of higher education as a competitive market, public reputation as an institutional priority associated with a greater capacity for attracting and satisfying students, [..]" (Paricio, 2017, p. 137).

The authors believe that students are not just stakeholders or just customers. Students are "involved customers" - customers with an active role in quality planning, assurance, assessment and improvement. Universities need to analyse the factors affecting students' understanding of the quality of higher education, as well as use these factors to create closer relationships between university staff and students.

\section{Method}

During the focus group discussion organized in 2017, 55 representatives of different Student Unions of HEIs of Latvia were interviewed. The interview took place during the Student Leaders Forum organized by the Student Union of Latvia to bring together the most active representatives of student councils. The aim of the discussion was to determine factors that students consider important for the quality of higher education. As a result, a list of 14 factors was prepared (Degtjarjova et al., 2018). Based on the literature review and factors obtained in focus group discussion, 32 factors affecting the quality of higher education were obtained.

During the second stage of the research, students' opinions were analysed. A questionnaire with 32 factors was drawn up. Cronbach's alpha was calculated to verify the consistency of the questions (Degtjarjova et al., 2018). In 2018, a survey sample was composed of the students of the Faculty of Engineering Economics and Management (FEEM) of Riga Technical University.

FEEM offers 24 study programs. The authors made a random selection of five students from each program. 120 questionnaires were handed out, 
the sample size at the 95 per cent validity level was calculated and 92 of questionnaires were filled out, which was considered a representative size (Bell et al., 2014). According to the error selection traditionally accepted in research practice, the representative error in the survey is $5 \%$. The random sample is calculated by the formula:

$$
n=\frac{t^{2} w(1-w) N}{\Delta^{2} N+t^{2} w(1-w)}=\frac{1,96^{2} \cdot 0,5 \cdot(1-0,5) \cdot 120}{0,05^{2} \cdot 120+1,96^{2} \cdot 0,5 \cdot(1-0,5)}=91,44
$$

where

$n$ - representative respondent base;

$t-1.96$ (if reliability is $95 \%$ );

$\mathrm{w}$ - relative frequency 0.5 ;

$N$ - general sample;

$\Delta$ - sampling error.

The survey instrument was a self-explanatory questionnaire. The Likert scale with four values from 0 to 3 ('very significant influence', 'significant influence', 'insignificant influence' and 'no influence') was used.

To make a factor correlation analysis, the Spearman rank correlation was used as a non-parametric test that is used to measure the degree of association between two variables.

\section{Results}

Factors obtained during the focus group discussion and literature review were grouped in three thematic groups - Study process (SP) with 14 factors, Support and resources (SR) with 11 factors, External factors and results (EFR) with 7 factors (see also Degtjarjova et al., 2018).

The SP thematic group includes factors related to the study process, i. e., SP1 Strict entrance requirements, SP2 Quality of educational content, SP3 Professors' competence, SP4 Strict and objective student evaluation, SP5 Clear achievement assessment and feedback, SP6 Quality of study materials, SP7 Teaching methods, SP8 Student-centred learning, SP9 Students' active involvement in research and projects, SP10 Employers and professionals' involvement in the study process, SP11 Internship opportunities, SP12 Study programs' relevance to labour market requirements, SP13 International guest speakers, SP14 Study process organization and administration.

The SR group includes factors related to support and resources that affect the student's life. Only the factors under the responsibility of the university were included in this group, i. e., the university staff are empowered to make decisions about them and can affect them. The SR factors are 
the following: SR1 Opportunity to study and work, SR2 International mobility, SR3 State subsidized studies according to quality criteria, SR4 Allowances, grants and other financial student support, SR5 Friendly administrative staff, SR6 Co-operation between the management and students, taking into account students' needs, SR7 Students' active involvement in student councils and in processes to improve quality, SR8 Co-operation among secondary schools and HEIs when working on educational content and requirements, SR9 Purposeful partnerships among all stakeholders - students, employers, HEI, professional organizations, etc., SR10 Extracurricular activities (sports, arts, etc.), SR11 Equipment and infrastructure relevant to the needs of the study process.

The EFR group includes external environmental factors that affect students' understanding of the quality of higher education, as well as factors related to the university performance, i. e., EFR1 HEI's reputation, EFR2 Prospects for future education, EFR3 Students' competitiveness on the labour market, EFR4 Strict accreditation requirements, EFR5 Competition among HEIs, EFR6 Equal study opportunities in the capital city Riga and regions, EFR7 Funding of higher education. The factors of EFR group cannot be influenced by the university at all or can be influenced very minimally.

Based on the thematic groups of the factors a questionnaire was developed. The Cronbach's alpha of the questionnaire (.826) indicates good internal consistency of questions. The internal consistency of the questions in each group was also determined (see Table 1). The obtained results also point to good internal coherence; for EFR the internal consistency of the questions was insignificantly lower.

Table 1. Cronbach's alpha

\begin{tabular}{|l|l|c|}
\hline$\#$ & Thematic group of the factors & Cronbach's alpha \\
\hline SP & Study process & .716 \\
\hline SR & Support and resources & .731 \\
\hline EFR & External factors and results & .691 \\
\hline
\end{tabular}

The aim of the survey was to find out students' opinion about factors' importance. The Likert scale was used. It is the most universal method for survey collection: it is easy for respondents to understand and use to express their own views freely, responses are very easy to code and use for further research and analysis. Values of factor significance were clear, easy to understand, students were given written instructions.

According to the results of the survey, factors were ranked from largest to smallest. Intervals between factors were analysed and four groups were formed: G1 - the most important factors with the score of 268-261 points, G2 and G3 - factors of medium importance with the score of 239-212 and 
199-158 points accordingly, and G4 - less important factors with the score of 133 points. Intervals of 1-2 points between the factors within the group were identified, whereas intervals between the groups G1-G2, G2-G3 and G3-G4 were 22, 13 and 25 points accordingly.

The most important factors were identified in the SP thematic group, these are SP2 Quality of study content and SP3 Professors' competence. The opposite trend was observed in the group of EFR - there are the less important factors, according to the students (Table 2).

Table 2. Number of factors by importance groups

\begin{tabular}{|l|c|c|c|c|}
\hline \multirow{2}{*}{ Thematic groups } & \multicolumn{4}{|c|}{ Number of factors (score interval) } \\
\cline { 2 - 5 } & $\begin{array}{c}\text { G1 } \\
(\mathbf{2 6 8 - 2 6 1 )}\end{array}$ & $\begin{array}{c}\text { G2 } \\
\mathbf{( 2 3 9 - 2 1 2 )}\end{array}$ & $\begin{array}{c}\text { G3 } \\
(\mathbf{1 9 9 - 1 5 8 )}\end{array}$ & $\begin{array}{c}\text { G4 } \\
(\mathbf{1 3 3})\end{array}$ \\
\hline Study process & $\mathbf{2 ( 1 0 0 \% )}$ & $\mathbf{6 ( 5 0 \% )}$ & $\mathbf{6 ( 3 5 \% )}$ & 0 \\
\hline $\begin{array}{l}\text { Support and } \\
\text { resources }\end{array}$ & 0 & $3(25 \%)$ & $\mathbf{7 ( 4 1 \% )}$ & $1(100 \%)$ \\
\hline $\begin{array}{l}\text { External factors and } \\
\text { results }\end{array}$ & 0 & $3(25 \%)$ & $\mathbf{4 ( 2 4 \% )}$ & 0 \\
\hline
\end{tabular}

In the next step of the research, statistically significant correlations between factors were identified. To make a factor correlation analysis, the following formula was used to calculate the Spearman rank correlation:

$$
\rho=1-\frac{6 \sum d_{i}^{2}}{n\left(n^{2}-1\right)}
$$

where

$\rho$ - the Spearman rank correlation

$d_{i}$ - the difference between the ranks of corresponding variables

$n$ - the number of observations

The number of correlations and the correlation strength were analysed in each group, between groups, as well as throughout the factor set.

As a result of correlation analysis, the biggest number of internal correlations is in the SP thematic group, i. e., 28 statistically significant correlations, whereas the factors of the SR thematic group have 22 internal correlations and the factors of the EFR thematic group have 15 internal correlations (Fig. 1).

The largest number of intergroup correlations are between SR and EFR factors - 28 statistically significant correlations. The factors of the SP and SR have 24 intergroup correlations, the factors of the SP and EFR have 16 intergroup correlations (Fig. 1). 


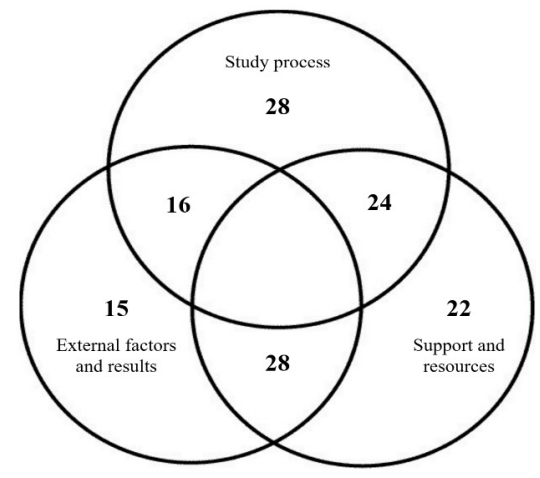

Figure 1. Internal and intergroup correlations

The factors with the largest number of correlations were analysed separately (Table 3). These factors have more intergroup correlations than internal.

As a result, two factors with the biggest number of correlations were obtained - these are SR5 Friendly administrative staff and EFR4 Strict accreditation requirements.

One of the most important factors SP3 Professors' competence has 12 statistically significant correlations, whereas SP2 Quality of study content is not identified as a factor with a big number of correlations.

Table 3. Factors with the largest number of correlations

\begin{tabular}{|l|l|c|c|}
\hline$\#$ & Factors & $\begin{array}{l}\text { Number of correlations } \\
\text { (incl. internal/intergroup } \\
\text { correlations) }\end{array}$ & $\begin{array}{l}\text { Group of } \\
\text { importance }\end{array}$ \\
\hline SP3 & Professors' competence & $12(6 / 6)$ & G1 \\
\hline SP5 & $\begin{array}{l}\text { Clear achievement assessment } \\
\text { and feedback }\end{array}$ & $11(4 / 7)$ & G2 \\
\hline SP7 & Teaching methods & $12(7 / 5)$ & G2 \\
\hline SP8 & Student-centred learning & $14(7 / 7)$ & G3 \\
\hline SR5 & Friendly administrative staff & $\mathbf{1 7}(7 / \mathbf{1 0})$ & G2 \\
\hline SR8 & $\begin{array}{l}\text { So-operation among secondary } \\
\text { schools and HEIs when working } \\
\text { requirements }\end{array}$ & $12(6 / 6)$ & G3 \\
\hline SR11 & $\begin{array}{l}\text { Equipment and infrastructure } \\
\text { relevant to the needs of the study }\end{array}$ & $13(5 / 8)$ & G3 \\
\hline EFR4 & Strict accreditation requirements & $\mathbf{1 7 ( 5 / 1 2 )}$ & G3 \\
\hline EFR5 & Competition among HEIs & $12(6 / 6)$ & G3 \\
\hline EFR7 & Funding of higher education & $14(5 / 9)$ & \\
\hline
\end{tabular}


Analysis of the statistically significant correlations between the previous factors showed that EFR4 has statistically significant correlations with all of the other factors (Table 4).

Table 4. Spearman's rank correlations of the factors with the largest number of correlations

\begin{tabular}{|l|l|l|l|l|l|l|l|l|}
\hline \multicolumn{7}{|c|}{ Statistically significant Spearman's correlation coefficients } \\
\hline EFR5 & $.365^{* *}$ & & & & & & & \\
\hline EFR4 & $.313^{* *}$ & $.519^{* *}$ & & & & & & \\
\hline SR11 & $.207^{*}$ & $.295^{* *}$ & $.298^{* *}$ & & & & & \\
\hline SR8 & $.302^{* *}$ & & $.291^{* *}$ & $.233^{*}$ & & & & \\
\hline SR5 & $.298^{* *}$ & $.224^{*}$ & $.214^{*}$ & $.329^{* *}$ & $.368^{* *}$ & & & \\
\hline SP8 & & & $.336^{* *}$ & $.268^{* *}$ & & $.237^{*}$ & & \\
\hline SP7 & & & $.212^{*}$ & & & & $.466^{* *}$ & \\
\hline SP5 & & $.282^{* *}$ & $.382^{* *}$ & & $.296^{* *}$ & $.297^{* *}$ & $.315^{* *}$ & \\
\hline SP3 & $.315^{* *}$ & & $.215^{*}$ & $.212^{*}$ & $.252^{*}$ & & $.235^{*}$ & $.278^{* *}$ \\
\hline & EFR7 & EFR5 & EFR4 & SR11 & SR8 & SR5 & SP8 & SP7 \\
\hline
\end{tabular}

Note. **99 per cent correlation, * 95 per cent correlation

Analysis of the factors with the small number of correlations showed that there are more internal correlations (within the thematic group SP, SR and EFR) and fewer intergroup correlations. Although factor SP2 Quality of educational content, according to the students, is the most important factor, the correlation analysis showed that factor SP2 has no statistically significant correlations with other factors (Table 5).

Table 5. Factors with a small number of correlations

\begin{tabular}{|l|c|c|}
\hline Factors & $\begin{array}{l}\text { Number of correlations } \\
\text { (incl. internal/intergroup } \\
\text { correlations) }\end{array}$ & $\begin{array}{l}\text { Group of } \\
\text { importance }\end{array}$ \\
\hline SP2 Quality of educational content & $\mathbf{0}$ & $\mathrm{G} 1$ \\
\hline SR1 Opportunity to study and work & 0 & $\mathrm{G} 3$ \\
\hline SR2 International mobility & $3(1 / 2)$ & $\mathrm{G} 3$ \\
\hline $\begin{array}{l}\text { SP4 Strict and objective student } \\
\text { evaluation }\end{array}$ & $4(3 / 1)$ & $\mathrm{G} 3$ \\
\hline SP6 Quality of study materials & $4(4 / 0)$ & $\mathrm{G} 2$ \\
\hline $\begin{array}{l}\text { SP12 Study programs' relevance to } \\
\text { labour market requirements }\end{array}$ & $4(3 / 1)$ & $\mathrm{G} 2$ \\
\hline SP13 International guest speakers & $4(3 / 1)$ & $\mathrm{G} 3$ \\
\hline $\begin{array}{l}\text { SP14 Study process organization and } \\
\text { administration }\end{array}$ & $4(2 / 2)$ & $\mathrm{G} 3$ \\
\hline
\end{tabular}


Correlation above .400 was determined within the thematic groups only, intergroup correlations above .400 were not identified (Table 6).

Table 6. Factors with correlation above .400

\begin{tabular}{|l|l|l|l|l|l|}
\hline SP5 & .451 & & & & \\
\hline SP8 & & .428 & .466 & .464 & \\
\hline SP11 & & & & & .581 \\
\hline SP12 & & & & & .417 \\
\hline & SP4 & SP6 & SP7 & SP9 & SP10 \\
\hline
\end{tabular}

\begin{tabular}{|l|l|l|l|l|}
\hline EFR6 & .411 & & & \\
\hline EFR5 & & .463 & .519 & \\
\hline EFR3 & & & & .413 \\
\hline & EFR7 & EFR1 & EFR4 & EFR2 \\
\hline
\end{tabular}

\begin{tabular}{|l|l|l|}
\hline SR4 & .485 & \\
SR7 & & .435 \\
& SR3 & SR6 \\
\hline
\end{tabular}

Analysis of the importance and correlations of the factors showed that there are five factors with the largest number of correlations and strong correlation rank, i. e., SP7 Teaching methods, SP8 Student-centred learning, EFR4 Strict accreditation requirements, EFR5 Competition among HEIs and EFR7 Funding of higher education.

\section{Discussion}

Quality standards and principles used by HEIs to a great extent depend on the national and international requirements and guidelines, the socio-economic conditions, the short-term goals and needs, the long-term strategy, the organizational life cycle, as well as the management style. The analysis of the students' understanding of the quality of higher education helps to involve the students in the university's quality management system more and encourage them to take active role in quality improvement. The factors can be used, on the one hand, to preserve stability, and, on the other hand, to promote development and innovations (Fig. 2).

The research was conducted in Riga, and 92 students of the RTU FEEM participated in the research. Due to the limitations of the study its results should not be generalized.

There are two factors that need to be deeply analysed: SP2 Quality of study content and EFR4 Strict accreditation requirements. SP2, according to the students, is the most important factor, at the same time, it has no statistically significant correlations with the other 31 factors. The importance of EFR4 was evaluated as G3 (i. e., closer to the unimportant factors), this factor has statistically significant correlations with all of the other factors with the largest number of correlations. 


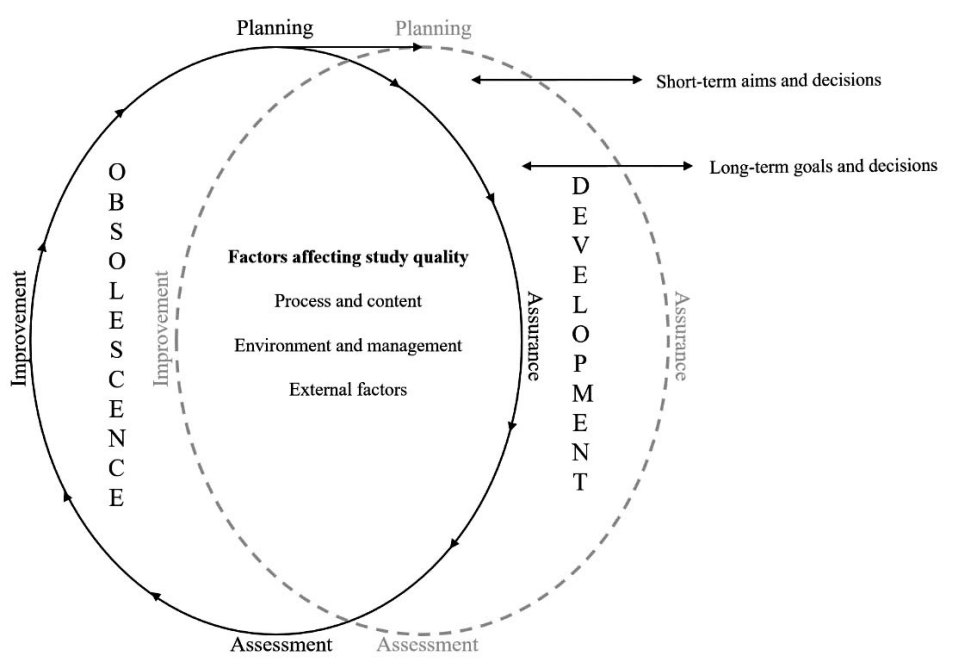

Figure 2. Factors as stability and development aspects (developed by authors)

\section{Conclusions}

According to the students, the most important factors were identified in the SP thematic group, as well as the biggest number of internal correlations was identified in the SP thematic group. The most important factors are SP2 Quality of study content and SP3 Professors' competence. Although SP2 Quality of educational content is the most important factor, the correlation analysis showed that factor SP2 has no statistically significant correlations with other factors.

Whereas the less important factors were identified in the EFR thematic group and the largest number of intergroup correlations was identified between SR and EFR factors.

SR5 Friendly administrative staff and EFR4 Strict accreditation requirements are the factors with the largest number of correlations. EFR4 has statistically significant correlations with all of the other factors with the largest number of correlations.

Some trends were observed: the more important is the factor, the greater is the number of relationships, and vice versa; the more important is the factor, the closer are relationships, and vice versa; the factors with the small number of correlations have more internal correlations within the thematic groups and less intergroup correlations.

According to the research the most important factors that affect the understanding of the quality of higher education, according to the students, are the factors of the SP thematic group, especially the quality of study content and professors' competence. 
Changes in one of the factors cause changes in other factors. In majority of cases the influence is not one-to-one, but one-to-many. That is why HEI need not only to identify the factors, but also to understand how they affect each other. It is important to analyse the influence of all of the factors separately and through the thematic groups, i. e. to distinguish weak factors and strong factors with broad influence and use this knowledge for improve the quality of higher education.

\section{References}

Bell M. L., Teixeira-Pinto A., McKenzie J. E., Olivier J. (2014). A myriad of methods: calculated sample size for two proportions was dependent on the choice of sample size formula and software. Journal of Clinical Epidemiology, 67, 601-605.

Chapleo, C., Sims, C. (2017). Stakeholder analysis in higher education: a case study of the University of Portsmouth. Perspectives: Policy and Practice in Higher Education, 14, 12-20. http://eprints.bournemouth.ac.uk/20955/1/Stakeholder\%20of\%20Uni\%20 $\% 282010 \% 29 \% 20$ Perspectives.pdf

Dahlgaard-Park, S. M. (2008). Reviewing the European excellence model from a management control view. The TQM Journal, 20(2), 98-119. https://doi.org/10.1108/ 17542730810857345

Degtjarjova I., Lapina I., Freidenfelds, D. (2018). Student as Stakeholder: "Voice of Customer" in Higher Education Quality Development. Marketing and Management of Innovations = Маркетинг і менеджмент інновацій, 2(1), 388-398. https://doi.org/ $10.21272 / \mathrm{mmi} .2018 .2-30$

Douglas, J., Douglas, A., Barnes, B. (2006). Measuring student satisfaction at a UK University. Quality Assurance in Education, 14(3), 251-267.

European University Association. (2015). Standards and Guidelines for Quality Assurance in the European Higher Education Area (ESG). http://bit.ly/2G3D134

Geryk, M. (2018). Universities of the future: universities in transition under the influence of stakeholders' changing requirements. Advances in Intelligent Systems and Computing, 594, 116-124. https://doi.org/10.1007/978-3-319-60372-8_12

Iljins, J., Skvarciany, V., Gaile-Sarkane, E. (2015). Impact of organizational culture on organizational climate during the process of change. Social and Behavioural Sciences, 213(1), 944-950. https://doi.org/10.1016/j.sbspro.2015.11.509

Iljins, J., Zeps, A., Ribickis, L. (2017). RTU Approach to Pursuing Excellence: Sustainable Integration of Internal Quality System in the Strategy Development. Pilot Project Review. In J. C. Quadrado, J. Berbabdo, J. Rocha (Eds.), Proceedings of the $45^{\text {th }}$ SEFI Annual Conference (pp. 661-668). Société Européenne pour la Formation des Ingénieurs. https://www.sefi.be/wp-content/uploads/SEFI_2017_PROCEEDINGS.pdf

Lanarès, J. (2008). Developing a Quality Culture. In E. Froment, J. Purser, L. Wilson (Eds.), EUA Bologna Handbook (pp. 1-27). Raabe Verlag.

Mainardes, E. W., Alves, H., Raposo, M. (2010). An exploratory research on the stakeholders of a university. Journal of Management and Strategy, 1(1), 76-88.

Marić, I. (2013). Stakeholder analysis of higher education institutions. Interdisciplinary Description of Complex Systems, 11(2), 217-226. 
Medne, A., Lapina, I., Zeps, A. (2020). Sustainability of a University's Quality System: Adaptation of the EFQM Excellence Model. International Journal of Quality and Service Sciences, 12(1), 29-43. https://doi.org/10.1108/IJQSS-09-2019-0108

Mihanović, Z. (2007). The role of customers in higher education: are students active stakeholders? Market-Trziste, 19(1), 115-132.

Ozoliņš, M., Stensaker, B., Gaile-Sarkane, E., Ivanova, L., Lapina, I., Ozolina-Ozola, I., Straujuma, A. (2018). Institutional attention to European policy agendas: exploring the relevance of instrumental and neo-institutional explanations. Tertiary Education and Management, 24(4), 338-350. https://www.tandfonline.com/doi/full/10.1080/135838 83.2018.1459820

Paricio, J. R. (2017). Students as customers: a paradigm shift in higher education. Debats, 2, 137-149.

Rossouw, D., Goldman, G. A. (2014). Strategic drivers for higher education. In G. A. Goldman, C. F. de Meyer, C. Kruger (Eds.), Proceedings of the $26^{\text {th }}$ Annual SAIMS Conference "Contemporary Management in Theory and Practice" (pp. 568-579). University of Johannesburg. https://studylib.net/doc/8256176/contemporary-management-in-theory-and-practice

Sahney, S., Banwet, D., Karunes, S. (2006). An integrated framework for total quality management implementation in higher education. The TQM Magazine, 16(6), 265-285.

Sallis, E. (2002). Total quality management in education. Kogan Page.

Schindler, L., Puls-Elvidge, S., Welzant, H., Crawford, L. (2015). Definitions of quality in higher education: a synthesis of the literature. Higher Learning Research Communications, 5(3), 3-13.

Setijono, D., Dahlgaard, J. J. (2007). Customer value as a key performance indicator (KPI) and a key improvement indicator (KII). Measuring Business Excellence, 11(2), 44-61.

Srikanthan, G., Dalrymple, J. F. (2002). Developing a holistic model for quality in higher education. Quality in Higher Education, 8(3), 215-224.

Shah, M., Nair, ChS. (2010). Enrolling in higher education: the perceptions of stakeholders. J. Inst. Res., 15(1), 9-15.

Støren, L. A., Aamodt, P. O. (2010). The Quality of Higher Education and Employability of Graduates, Quality in Higher Education, (16)3, 297-313.

Straujuma, A., Lapina, I., Gaile-Sarkane, E., Ozolins, M. (2017). Policies, legislation and regulatory compliance governance impact on strategic management of higher education and research institutions in Latvia. Proceedings of the $21^{\text {st }}$ World Multi-Conference on Systemics, Cybernetics and Informatics, 2 (pp. 69-74). International Institute of Informatics and Systemics. http://iiisci.org/journal/CV\$/sci/pdfs/SA657WP17.pdf

Thanassoulis, E., Dey, P. K., Petridis, K., Goniadis, I., Georgiou, A. C. (2017). Evaluating higher education teaching performance using combined analytic hierarchy process and data envelopment analysis. Journal of the Operational Research Society, 68, 431-445. 